\title{
A new southernmost record of Elaenia chiriquensis Lawrence, 1865 (Passeriformes, Tyrannidae) in Brazil
}

\author{
João Vitor Perin Andriola, ${ }^{1}$ Amanda Perin Marcon ${ }^{2}$
}

1 Universidade Regional Integrada do Alto Uruguai e das Missões, Campus de Erechim, Laboratório de EcoFauna, Departamento de Ciências Biológicas, Avenida Sete de Setembro, Fátima, CEP 99709-510, Erechim, RS, Brazil. 2 Universidade Federal do Rio Grande do Sul, Instituto de Biociências, Departamento de Zoologia, Avenida Bento Gonçalves, CEP 91540-000, Porto Alegre, RS, Brazil.

Corresponding author: João Vitor Andriola, jvandriola@gmail.com

\begin{abstract}
Species of the genus Elaenia are difficult to distinguish from one another using only morphological characteristics. In Brazil, Elaenia chiriquensis occurs from northern Paraná to Roraima and is absent in Santa Catarina and Rio Grande do Sul states. Using audio and photographic evidence, as well as the comparison of sonograms, we confirm the occurrence of this species $700 \mathrm{~km}$ southwest of its previously known distribution. Our new record is from Palmas, Paraná, only $600 \mathrm{~m}$ from the border with Água Doce, Santa Catarina, which suggests the possibility that this species also occurs in this state. Deforestation for monocultures and pastures might have contributed to this species' expansion in the Atlantic Rainforest biome.
\end{abstract}

Keywords

Palmas; Paraná; highland fields; range extension; Lesser Elaenia; ecology.

Academic editor: Nárgila Moura | Received 8 April 2017 | Accepted 6 October 2017 | Published 22 December 2017

Citation: Andriola JVP, Marcon AP (2017) A new southernmost record of Elaenia chiriquensis Lawrence, 1865 (Passeriformes, Tyrannidae) in Brazil. Check List 13 (6): 1097-1100. https://doi.org/10.15560/13.6.1097

\section{Introduction}

The elaenians, genus Elaenia Sundevall, 1836, are a group of passeriform birds belonging to the family Tyrannidae, which have a medium-sized body and faded colors (Fig. 1). Species are very similar and are more easily and correctly identified by their vocalization (Ridgely et al. 2016). These species present geographical variations and the same species may present different dialects in different regions (Krebs and Kroodsma 1980). The Lesser Elaenia, E.chiriquensis Lawrence1865, inhabits shrub fields, where it feeds on small insects and small fruits (Gimenes et al. 2007). It is the smallest elaeninan, and its vocalization is a determinant factor for correct identification (Gwynne et al. 2010).
Elaenia chiriquensis usually occurs at elevations below 1100 m (Ridgely et al. 2016), and its distribution extends from Costa Rica and Panama to northeastern Argentina; in Brazil it is not known to be resident in southern Amazonia and is not known to occur in Santa Catarina and Rio Grande do Sul (Schauensee 1982, Marini and Cavalcanti 1990, Sick 1997). This species migrates to the Central Region of Brazil; there it reproduces in the Cerrado from September to December and has 2 reproductive peaks, 1 in October and 1 in November (Medeiros and Marini 2007). It does not occur in forests of the Atlantic Rainforest, but it can be found in highland field areas in northernmost Paraná (Sigrist 2014). The conservation status of E. chiriquensis is Least Concern (IUCN 2017). 


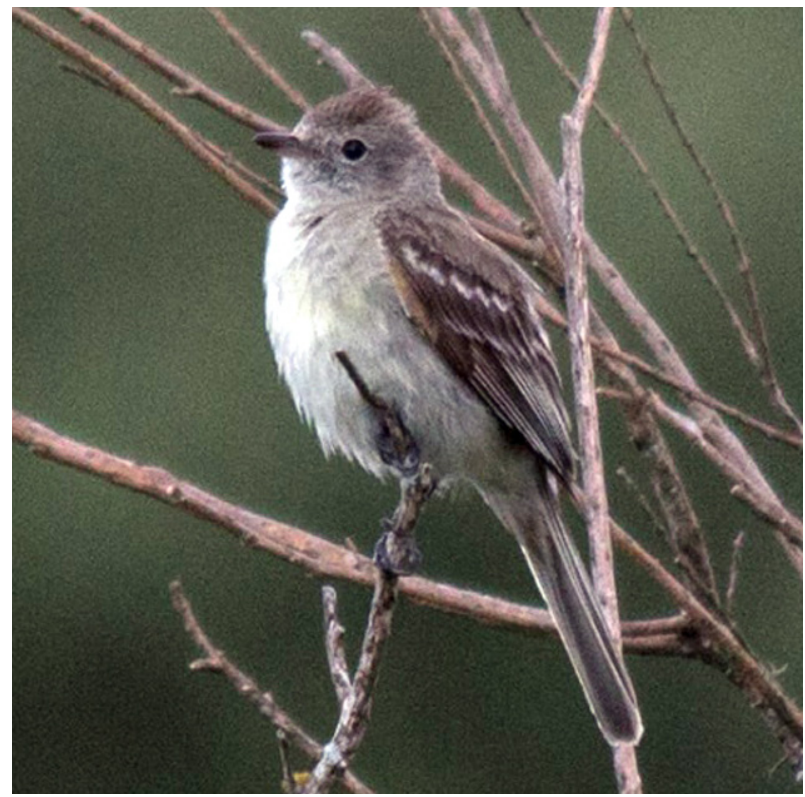

Figure 1. Individual of Elaenia chiriquensis (Lawrence, 1865) recorded in the municipality of Palmas, Paraná, Brazil. Photograph by J.V.P. Andriola.

\section{Methods}

The audio recordings were made with a Canon Eos Rebel T5i digital SLR camera, and the recorded sound was edited in Avisoft-SASLab (v. 5.2.09) software for sound cutout, amplification, and noise suppression. The audio recording was deposited at the Xeno-Canto Foundation under the number XC355792 (http://www. xeno-canto.org/355792). Literature sources (Schauensee 1982, Marini and Cavalcanti 1990, Sick 1997) and citizen-science websites (WikiAves 2017, Xeno-Canto Foundation 2017, eBird 2017, Táxeus 2017, Macaulay Library 2017) were consulted on the occurrence of $E$. chiriquensisin Brazil. We identified this species by comparing sonograms of its song (Xeno-Canto Foundation 2017, Macaulay Library 2017). We mapped this species using QGIS (v. [2.18.6]), highlighting the historical records for the state of Paraná, our new record from the city of Palmas, and the possible occurrence in the city of Água Doce, Santa Catarina.
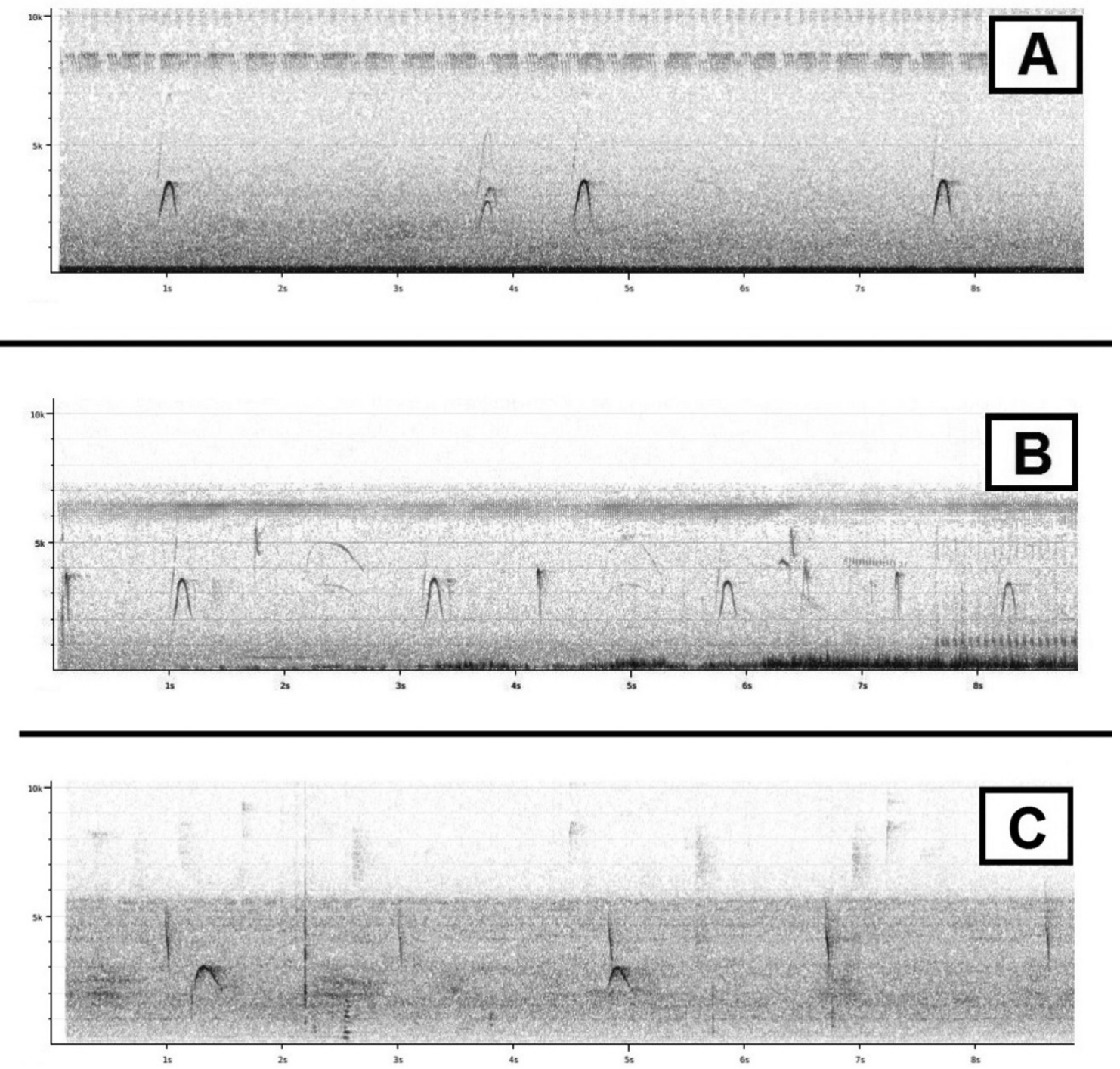

Figure 2. Comparison of (A) a sonogram of the species Elaenia chiriquensis (sonogram by Godoy 2010) with (B) the sonogram of one of the individuals recorded in Palmas, PR, and with (C) a sonogram of Elaenia chilensis (sonogram by Meyer 2014). Source: @Xeno-Canto Foundation 2017. 

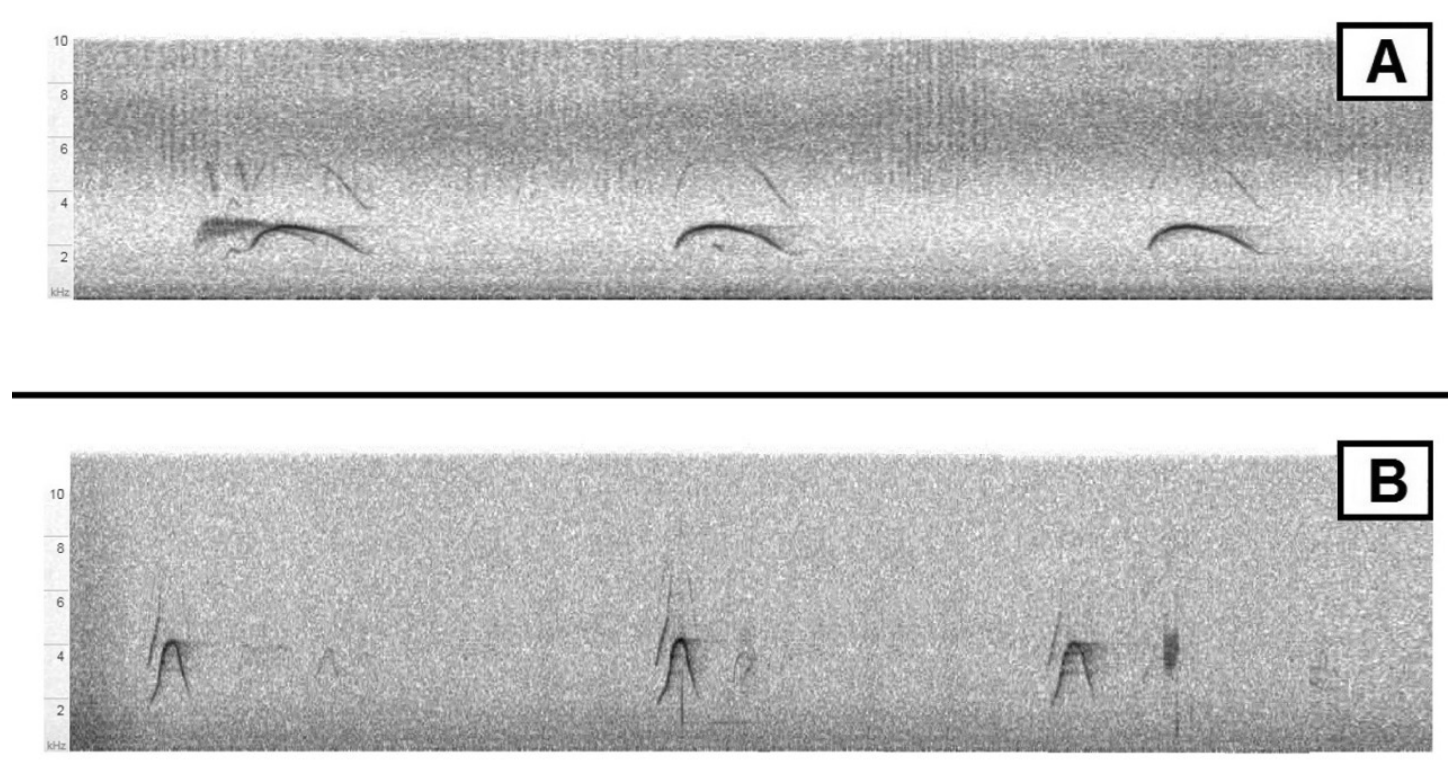

Figure 3. Comparison of (A) a sonogram of the species Elaenia chilensis (sonogram by Areta 2011) with (B) a sonogram of the species Elaenia chiriquensis (sonogram by Remold 1998). Source: @Macaulay Library 2017.

\section{Results}

New record. Brazil: Parana: city of Palmas (26 $34^{\prime} 47^{\prime \prime}$ S, $051^{\circ} 46^{\prime} 28^{\prime \prime} \mathrm{W}, 1239 \mathrm{~m}$ elev.), observer João Vitor Andriola, 26 January 2017, ca 11:00 h, 3 adult individuals recorded in a highland field remnant. The 3 individuals constantly vocalized from the tops of shrubs, sometimes alternating their perches.

Identification. Because there are almost no obvious morphological differences among species of Elaenia, the individuals were identified only by comparison of the sonograms of their song, although we also photographed these individuals (Fig. 1). All southern and centralwestern sonograms of E. chiriquensis deposited in the Xeno-Canto Foundation and in the Macaulay Library were compared with our recordings to avoid differences in dialects. The song of E. chiriquensis is characterized as a treble sound on a $0.2 \mathrm{~ms}$ loop, emitting approximately 1 chirp per $2 \mathrm{sec}$, with a frequency of around $5 \mathrm{kHz}$. The Chilean Elaenia, Elaenia chilensis Hellmayr, 1927, also occurs in Paraná and has a very similar vocalization. However, the sonogram of $E$. chilensis differs by lasting slightly longer, approximately $0.4 \mathrm{~ms}$ and having a lower tone than the sonogram of $E$. chiriquensis, with frequency of approximately $4 \mathrm{kHz}$ (Figs 2, 3). Other elaenians that occur in South Brazil do not have similar vocalizations.

\section{Discussion}

As other species of Elaenia, E. chiriquensis is difficult to identify by only looking at its morphology. Because this species is not large, not colorful, and requires study of its vocalization, it almost never holds the observer's attention. Thus, this species is possibly under- or unrecorded from other regions because of the lack of attention by observers. Until now, the southernmost known record of this species in Brazil is at Morretes, Paraná $\left(25^{\circ} 35^{\prime}\right.$
17" S, 048 55'10"W) (Breves 2016). Outside of Brazil, there is a record from Itapúa, Paraguay, $23 \mathrm{~km}$ south of Palmas (eBird 2004); however, it lacks photographs or audio and its veracity cannot be proved. Our record from Palmas expands the Brazilian distribution of this species by approximately $300 \mathrm{~km}$ southwest and $100 \mathrm{~km}$ south (Fig. 4) from the nearest known records and fills a distribution gap of more than $700 \mathrm{~km}$ if Paraguay record is accepted. Elaenia chiriquensis is absent from the state of Santa Catarina (Sick 1997), but our record was less than $600 \mathrm{~m}$ from the border with the city of Água Doce, Santa Catarina, which suggest that this species is likely to occur at least in the northern part of this state.

The city of Palmas is within the Atlantic Rainforest biome, and the area where we observed E. chiriquensis is predominantly shrub vegetation, composed mostly of Baccharis spp. (Asteraceae) with small fragments of Araucaria Moist Forest. The land is mainly used for crop and Pinus spp. monocultures and fruit orchards, but other impacts on the environment are road construction and the constant movement of people.

Elaenia chiriquensis inhabits fields with shrubs in the Cerrado biome (Gimenes et al. 2007), but our record of this species in Paraná lies within the Atlantic Moist Forest biome. As in the rest of the South Region of Brazil, most of the Atlantic Forest habitat has been replaced by agriculture and pasture for livestock, transforming a once forested landscape into monoculture fields (MMA 2007). These alterations could have contributed to this species expanding into new areas where it did not occur before, as new territory became suitable.

\section{Acknowledgements}

We thank Fernando Igor de Godoy. Juan Ignacio Areta and Douglas Meyer for permitting us to use their sonogram. We also thank Jonas Claudiomar Kilpp for preparing the map and Nárgila Moura for reviewing the manuscript. 


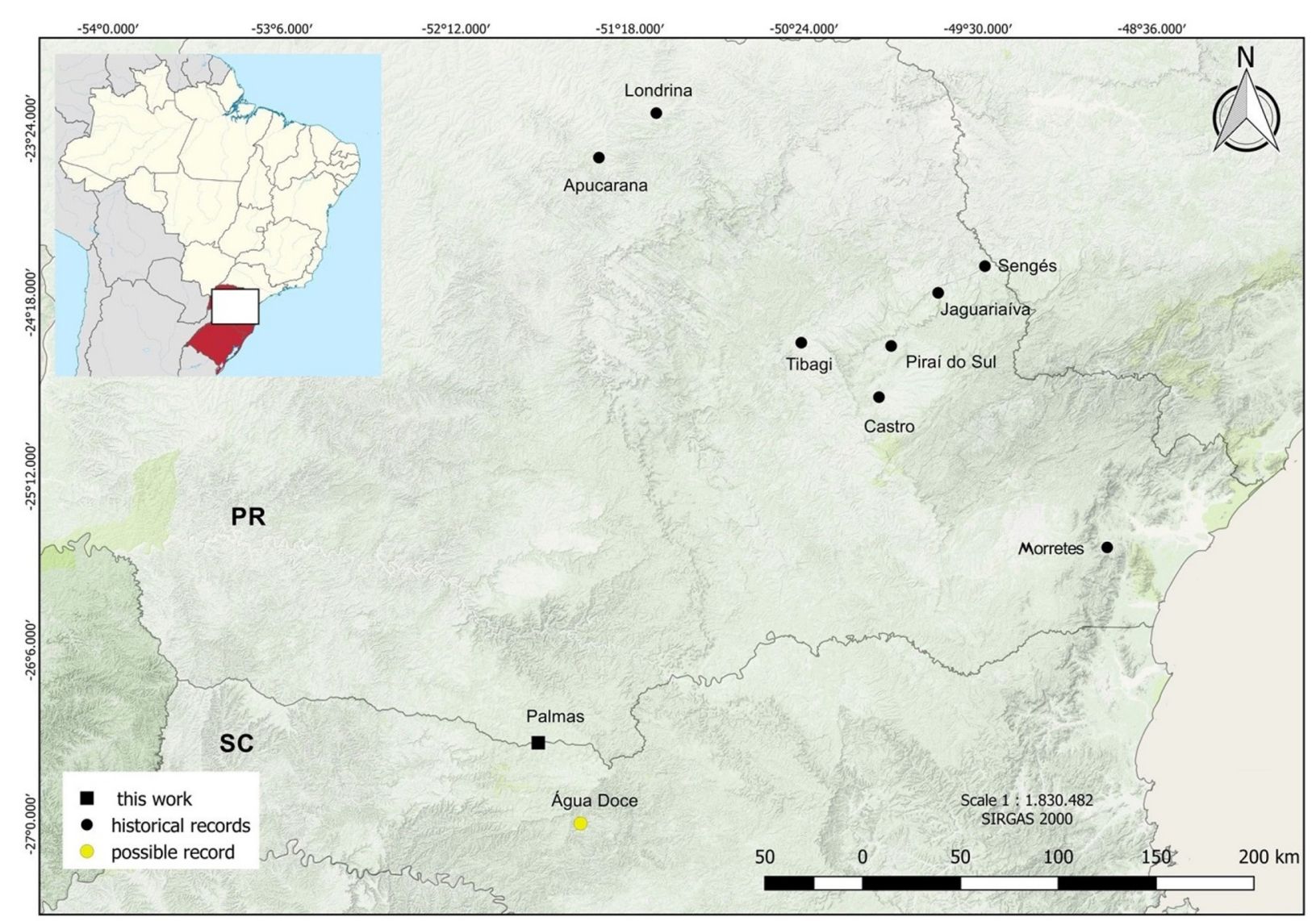

Figure 4. Species distribution map in Paraná, containing the new record in the municipality of Palmas and the possible occurrence for the city of Água Doce, SC. Red region marked on top-left smaller map represents the South Region of Brazil (Rio Grande do Sul, Santa Catarina and Paraná States). Map produced by J.C. Kilpp.

\section{Authors' Contributions}

JVA collected the data; JVA and APM wrote the text.

\section{References}

Andriola JVP (2017) XC355792. http://www.xeno-canto.org/355792. Accessed on: 2017-2-15.

Areta JI (2000) ML 177071. https://macaulaylibrary.org/audio/177071. Accessed on: 2017-9-11.

Breves L (2016) Checklist S32752010. http://ebird.org/ebird/view/ checklist/S32752010. Accessed on: 2017-8-23.

eBird (2017) Lesser Elaenia. https://goo.gl/K2xMCc. Accessed on: 2017-8-23.

eBird (2004) Lista S20168618. http://ebird.org/ebird/view/checklist/ S20168618. Accessed on: 2017-9-11.

Gimenes MR, Lopes EV, Loures-Ribeiro A, Mendonça LB, Anjos L (2007) Aves da Planície Alagável do Alto do Rio Paraná. Eduem, Maringá, $281 \mathrm{pp}$.

Godoy FI (2010) XC186274. http://www.xeno-canto.org/186274. Accessed on: 2017-2-19.

Gwynne JA, Ridgely RS, Tudor G, Argel M (2010) Aves do Brasil Pantanal \& Cerrado. Editora Horizonte, São Paulo, 322 pp.

IUCN (2017) The IUCN Red List of threatened species. Version 20163. International Union for Conservation of Nature. http://www. iucnredlist.org/. Accessed on: 2017-2-19.

Krebs JR, Kroodsma DE (1980) Repertoires and geographical variation in bird song. Advances in the Study of Behavior 11: 143-177. https://doi.org/10.1016/S0065-3454(08)60117-5

Macaulay Library (2017) Chibum Elaenia chiriquensis. http://goo.gl/ pQMPyj. Accessed on: 2017-9-11.

Macaulay Library (2017) Guaracava-de-crista-branca Elaenia albiceps chilensis. https://goo.gl/G9ZxQD. Accessed on: 2017-9-11.

Marini MÂ, Cavalcanti RB (1990) Migrações de Elaenia albiceps chilensis e Elaenia chiriquensis albivertex (Aves: Tyrannidae). Boletim do Museu Paraense Emílio Goeldi, série Zoologia 6: 59-67.

Medeiros RCS, Marini MÂ (2007) Biologia reprodutiva de Elaenia chiriquensis (Lawrence) (Aves, Tyrannidae) em Cerrado do Brasil Central. Revista Brasileira de Zoologia 24 (1): 12-20. https://doi. org/10.1590/S0101-81752007000100002

Meyer D (2014) XC32381. http://www.xeno-canto.org/323819. Accessed on: 2017-8-23.

MMA (Ministério do Meio Ambiente) (2007) Áreas prioritárias para a conservação, uso sustentável e repartição de benefícios da biodiversidade brasileira: atualização-Portaria MMA nº 09, de 23 de janeiro de 2007. Ministério do Meio Ambiente, Brasília, 15 pp.

Remold HG (1998) ML114882. https://macaulaylibrary.org/audio/ 114882. Accessed on: 2017-9-11.

Ridgely RS, Gwynne JA, Tudor G, Argel M(2015) Aves do Brasil Mata Atlântica do Sudeste. Editora Horizonte, São Paulo, 418 pp.

Schauensee RMD (1982) A Guide to the Birds of South America. Intercollegiate Press, Philadelphia, 449 pp.

Sick H (1997) Ornitologia Brasileira, uma Introdução. Nova Fronteira, Rio de Janeiro, 912 pp.

Sigrist T (2014) Guia de Campo Avis Brasilis: Avifauna Brasileira. Avis Brasilis, Vinhedo, 608 pp.

Táxeus (2017) Elaenia chiriquensis. http://www.taxeus.com.br/especie/ elaenia-chiriquensis. Accessed on: 207-8-23.

Wikiaves (2017) Chibum. http://www.wikiaves.com.br/chibum. Accessed on: 2017-2-15.

Xeno-Canto Foundation (2017) Chibum - Elaenia chiriquensis. http:// www.xeno-canto.org/species/Elaenia-chiriquensis. Accessed on: 2017-2-19. 